\title{
On the problematique of decolonisation as a post-colonial endeavour
}

\begin{abstract}
Inasmuch as postmodernism has enjoyed commonalities and convergences with postcolonialism, the relationship between the two has been a somewhat uncomfortable one. Does the demise of postmodernism, therefore, open the path for a re-emergence and re-consideration of post-colonialism? Conceptions of post-colonialism lean extensively on the idea of turning the world inside out, and upside down so that it might be seen differently, or how it might otherwise be. Post-colonialism uses a post-structuralist language to bring into contestation binary understandings of dominance/subjugation, centre/margin, and superiority/inferiority. Implicit in this contestation is that an undermining of hegemonic discourses and ideologies will redress historical imbalances, inequalities and displacements. In this regard post-colonialist theory has bode well for post-apartheid discourses in South Africa. Of late, however, postcolonialism has uncontestably - and rather recklessly - been conflated with, and subsumed into calls for decolonisation.
\end{abstract}

Calls for decolonising the university curriculum and space, have found renewed impetus in the \#feesmustfall campaigns, which have not only disrupted classes, but have left numerous campuses vandalised. What the \#feesmustfall campaigns have revealed is a complex collision between the postcolonial binaries of dominance/subjugation, centre/margin, and superiority/inferiority - all the while underscored by a grand narrative of Race. There are two immediate oddities about the calls for decolonisation. Firstly, there is seemingly no consensus, let alone clarity about what a decolonised university in South Africa might look like. Secondly, and ironically, the very violence, which post-colonialism is meant to offset, has defined the decolonisation project, thus far.

Following the above, and in response to the question: 'What comes after postmodernism?' I offer the following points of discussion in this article. Firstly, calls for decolonisation by South African university students is a misnomer, because the language of decolonisation cannot be extricated from colonisation. Secondly, in light of the promises of openness, and reimaginations, promulgated by post-modernism, it seems rather contradictory to look towards constructions of other forms of 'post', unless the intention is to return to what was before. Thirdly, South Africa is not in need of a decolonisation project. It is, however, in need of an 
educational theory that is less concerned with what has already been - that is, being trapped in the abyss of a 'post'. It should, therefore, be more concerned with (re)-evoking that which already resides in all of us, and that which we might yet become.

\section{Post-colonialism and Decolonisation}

The recent student uprisings at South African universities, which started in 2015, have, once again, echoed calls for transformation and decolonisation by 'ending the domination of Western epistemological traditions, histories and figures' (Molefe, 2016: 32). Many would agree with Mbembe's (2016: 32), assertion that there is 'something anachronistic, something entirely is wrong with a number of institutions of higher learning in South Africa. There is something profoundly wrong when, for instance, syllabuses designed to meet the needs of colonialism and Apartheid should continue well into the liberation era'. And, with McKaiser's view (2016), that the South African higher education system 'remains a colonial outpost', which continues to reproduce 'hegemonic identities instead of eliminating hegemony'.

The problems which continue to beset higher education in South Africa are protracted, not only because of undelivered promises of access, social equity and redress, but because it is seemingly mired in an obdurate tension in terms of its own values and goals. One of these values is the restoration of values itself. Like colonialism, apartheid succeeded in depicting black people as not entirely human, as a colour without any value. It is not simply devaluing another human being, it is stating that that human being does not have the value of being human, and hence should be treated as if he or she does not matter. The frustration, therefore, of protesting students, as they bang against university doors, transcend that of mere external access. Instead, it is about being seen, and mattering. That this tension might perceivably find relief in conceptions and practices of decolonisation, necessarily compels one to take stock not only of decolonisation, but of decoloniality as well. These two terms are often used interchangeably, and as will be pointed out later in this article, rather recklessly. In a very concise sense, if coloniality, following Maldonado-Torres (2016: 1), can be described as the perpetuation of hegemonic identities, then, decoloniality, following McKaiser (2016), signals the elimination of hegemony. But, what does this mean? More specifically, what does the idea of decoloniality as a disruption of hegemony mean firstly, to a post-colonial, and secondly, to a post-apartheid society, such as South Africa? On the face of it, the same question might be directed at both coloniality and decoloniality: whose voice, and hence, hegemony, is being perpetuated? 
Let's start by looking at what decoloniality is, and what decolonisation is not. This will help us to make sense of a necessary differentiation between coloniality and colonisation. MaldonadoTorres (2016: 10) explains, that for the most part, the concepts of colonialism and decolonisation are considered 'as ontic concepts that specifically refer to specific empirical episodes of socio-historical and geopolitical conditions. In this sense, colonialism and decolonization are usually depicted as 'historical episodes... locked in the past, located elsewhere, or confined to specific empirical dimensions' (Maldonado-Torres, 2016: 10). Our understanding of decolonization, states Mamdani (2016: 79), has changed over time: from political, to economic to discursive (epistemological). The epistemological dimension of decolonization, continues Mamdani (2016: 79), has focused on the categories 'with which we make, unmake and remake, and thereby apprehend, the world. It is intimately tied to our notions of what is human, what is particular and what is universal'. This view echoes that of Fanon (2004: 63), when he states that 'decolonisation is quite simply the substitution of one 'species' of mankind by another. The substitution is unconditional, absolute, total, and seamless'. In agreement, Mamdani (106: 79), maintains that the political understanding of decolonization 'has moved from one limited to political independence, independence from external domination, to a broader transformation of institutions, especially those critical to the reproduction of racial and ethnic subjectivities legally enforced under colonialism' - as depicted in the student protests at South African universities.

As an historical process, explains Fanon (2004: 64), decolonisation 'fundamentally alters being, and transforms the spectator crushed to a nonessential state into a privileged actor...It infuses a new rhythm, specific to a new generation of men, with a new language and a new humanity'. Underscoring Fanon's description is a particular understanding of decolonisation as not only a transition from one state to another, but as a process of restoration, repair and (re)being. That is, if colonisation is that which ensured the de-basement and de-humanisation of the colonised, then decolonisation, is, in fact, the erasure of all prefixes, which stripped people of being. The question, however, is: can colonisation be erased, as de-colonisation seemingly implies? Or, is decolonisation, as Grosfuguel (2007: 220) argues, a myth, which 'obscures the continuities between the colonial past and current global colonial/racial hierarchies and contributes to the invisibility of 'coloniality' today'?

To Grosfuguel (2007: 219), coloniality (a concept, first introduced by Anibal Quijano) is neither reducible to the presence or absence of a colonial administration, nor to the political/economic 
structures of power. Coloniality, explains Maldonado-Torres (2007: 243), is different from colonialism:

Colonialism denotes a political and economic relation in which the sovereignty of a nation or a people rests on the power of another nation, which makes such a nation an empire. Coloniality, instead, refers to long-standing patterns of power that emerged as a result of colonialism, but that define culture, labour, intersubjectivity relations, and knowledge production well beyond the strict limits of colonial administrations. Thus, coloniality survives colonialism. It is maintained alive in books, in the criteria for academic performance, in cultural patterns, in common sense, in the self-image of peoples, in aspirations of self, and so many other aspects of our modern experience. In a way, as modern subjects we breathe coloniality all the time and every day.

The elimination of colonial administrations does not, therefore, amount to an idea of decolonisation, or a 'postcolonial' world; instead the 'colonial power matrix' remains intact (Grosfuguel, 2007: 219). Although colonial administrations have indeed been dismantled, coloniality, continues Grosfuguel (2007: 219), allows us 'to understand the continuity of colonial forms of domination after the end of colonial administrations'. Hence, while colonialism encompasses 'colonial situations', enforced through colonial administration, coloniality addresses 'colonial situations' within current contexts (Grosfuguel, 2007: 219). To this end, Maldonado-Torres (2016: 10) contends that:

If coloniality refers to a logic, metaphysics, ontology, and a matrix of power that can continue existing after formal independence and desegregation, decoloniality refers to efforts at rehumanizing the world, to breaking hierarchies of difference that dehumanize subjects and communities and that destroy nature, and to the production of counterdiscourses, counter-knowledges, counter-creative acts, and counter-practices that seek to dismantle coloniality and to open up multiple other forms of being in the world. (10)

In sum, colonialism is not a historical artefact; it has not been relegated to the past with the departure or removal of colonialist masters. The relics and absorption of colonialism exist within deeply embedded matrices of power - giving rise to 'coloniality of power', which, as Grosfuguel (207: 219 -220) explains, 'refers to a crucial structuring process in the modern/colonial world-system that articulates peripheral locations...' Coloniality, says Madonado-Torres (2016: 19), is a peculiar construction of knowledge, power and being that divides the worlds into zones of being and not-being human. It is a construction of knowledge, which can only be undone through an undoing of that construction. Maldonado-Torres (2018: 117) explains that decoloniality refers to the 
'dismantling of relations of power and conceptions of knowledge that foment the reproduction of racial, gender, and geo-political hierarchies that came into being or found new and more powerful forms of expression in the modern/colonial world'. What distinguishes decoloniality from other existing critical social theories, states Mignolo (2007: 159), 'is its locus of enunciations and its genealogy—which is outside of Europe. Decoloniality can be best understood as a pluriversal epistemology of the future-a redemptive and liberatory epistemology that seeks to de-link from the tyranny of abstract universals'.

Mignolo, W. D., 'Introduction: Coloniality of Power and De-colonial Thinking', Cultural Studies, 21(2-3) (2007): 159.

This is why decoloniality can be understood as first philosophy: it is the effort to restore love and understanding. This includes the critique of coloniality, on the one hand, and the affirmation of all practices and knowledges that promote love and understanding, on the other. Without a subject who can love and communicate

with others, and without forms of wisdom, knowledge, and objectivity that cannot so easily lend itself to the anxieties, fears, and forms of bad faith of cognitive subjects, there cannot be any true philosophy. (22)

It is often said that philosophy starts with a change of attitude. In a context defined by

modernity/coloniality, the emergence of philosophy depends on the formation of a decolonial attitude. The decolonial attitude is part of a decolonial turn away from the "down turn" of metaphysical catastrophe. It is a turn to the metaphysical and material restoration of the human and the human world, including nature. The first philosophers are therefore those who, oriented by a decolonial attitude, commit to creating the conditions for love and understanding. These are decolonial activists, artists, theorists and intellectuals, as well as community leaders and everyone committed to undermine coloniality and to promote decoloniality. (22)

The most basic expression of the decolonial turn is at the level of attitude, leading to the formation of a decolonial attitude. (23)

That is, attitude is the definition of an orientation towards knowledge, power, and

being that can make the subject turn decolonial.

In contrast, coloniality and decoloniality refer to the logic, metaphysics, ontology, and matrix of power created by the massive processes of colonization and decolonization. (10)

The mythology about the 'decolonization of the world' obscures the 
continuities between the colonial past and current global colonial/racial

hierarchies and contributes to the invisibility of 'coloniality' today. (220)

In sum, part of the Eurocentric

myth is that we live in a so-called 'post'-colonial era and that the world and, in particular, metropolitan centers, are in no need of decolonization. In this conventional definition, coloniality is reduced to the presence of colonial administrations. However, as the work of Peruvian sociologist Anibal Quijano $(1993,1998,2000)$ has shown with his 'coloniality of power' perspective, we still live in a colonial world and we need to break from the narrow ways of thinking about colonial relations, in order to accomplish the unfinished and incomplete twentieth century dream of decolonization. This proposal invite us to examine new decolonial utopian alternatives beyond Eurocentric and 'Thirdworldist' fundamentalisms. (221)

The reason for this is not difficult to ascertain: the globe is still going through the globalization and solidification, even amidst various crisis, of a civilization system that has coloniality as its basis.

Therefore, the continued unfolding of Western modernity is also the reinforcement, through crude and vulgar repetitions as well as more or less creative adjustments, of coloniality. This is reflected in contemporary "development" policies, nation-state building practices, widespread forms of policing, surveillance, and profiling, various forms of extractivism, the increasing concentration of resources in the hands of the few, the rampant expression of hate and social phobias, and liberal initiatives of inclusion, among other forms of social, economic, and political control. (1)

They become objects for a subject that is considered to be already beyond the influence of colonialism and the imperative of decolonization. In like manner, from

this perspective, those who make the questions about the meaning and significance of colonialism and decolonization inevitably appear as anachronic-as if they exist in a different time and therefore can never be entirely reasonable.

In contrast, coloniality and decoloniality refer to the logic, metaphysics, ontology, and matrix of power created by the massive processes of colonization and decolonization. (10)

If coloniality refers to a logic, metaphysics, ontology, and a matrix of power that can continue existing after formal independence and 
desegregation, decoloniality refers to efforts at rehumanizing the world, to breaking hierarchies of difference that dehumanize subjects and communities and that destroy nature, and to the production of counterdiscourses, counter-knowledges, counter-creative acts, and counterpractices that seek to dismantle coloniality and to open up multiple other forms of being in the world. (10)

When South Africa transitioned from a post-colonial and apartheid society to a post-apartheid democracy in 1994, /post-colonial to a postapartheidAddressing colonialism and decolonization as anything more than past episodes or events raises anxieties and fears: anxieties about the legitimacy of the normative citizen-subject and the social, political, and economic order that sustains it, and fears

about the very presence and the potential action of those who typically address these topics in this way-that is, the colonized. (8)

Andreotti (2010: 234) considers the role of global citizenship education as one of decolonization - that is, "to provide analyses of how these inequalities came to exist, and tools to negotiate a future that could be "otherwise". Similarly, Pike (2008: 45-46) maintains that global citizenship education challenges educators to acknowledge the ever-changing patterns of relationships among human communities, as well as their opportunities for meaningful participation' (10)

might be conceived as either ending of hegemonic identities, or the perpetuation of subjugated or othered identities. the can be ex is, and hence, what col, and hence what forces one to take stock not only of ns of decolonisation and decoloniality, but To Maldonado-Torres (2016: 1), the ongoing perpetuation of hegemonic identities is a confirmation of the creative adjustments of coloniality in the unfolding of western modernity.

\footnotetext{
I begin by problematizing both the concept and the institutional history of the university, in its European and African contexts. My point is to underline the specifically modern character of the university as we know it and its genesis in post-Renaissance Europe. The European university emerged from Western Christianity, in the 12th and 13th centuries, and was institutionalized in Berlin in the 19th
} 
century, as the home of the study of this undifferentiated human.

To Maldonado-Torres (2016: 1), the ongoing perpetuation of hegemonic identities is a confirmation of the creative adjustments of coloniality in the unfolding of western modernity.

To be perfectly frank, I have to add that our task is rendered all the more complex because there is hardly any agreement as to the meaning, and even less so the future, of what goes by the name 'the university' in our world today.

The harder I tried to make sense of the idea of 'decolonization' that has become the rallying cry for those trying to undo the racist legacies of the past, the more I kept asking myself to what extent we might be fighting a complexly mutating entity with concepts inherited from an entirely different age and epoch. Is today' s Beast the same as yesterday' s or are we confronting an entirely different apparatus, an entirely different rationality - both of which require us to produce radically new concepts? (Mbembe, 2016: 32)

. Mbembe (2016:32) argues that 'there is something profoundly wrong when ... syllabuses designed to meet the needs of colonialism and apartheid should continue well into the liberation era'. This is why it is of paramount importance to bring about fundamental epistemological change at institutions of higher learning.

To be perfectly frank, I have to add that our task is rendered all the more complex because there is hardly any agreement as to the meaning, and even less so the future, of what goes by the name 'the university' in our world today. The harder I tried to make sense of the idea of 'decolonization' that has become the rallying cry for those trying to undo the racist legacies of the past, the more I kept asking myself to what extent we might be fighting a complexly mutating entity with concepts inherited from an entirely different age and epoch. Is today' s Beast the same as yesterday' $s$ or are we confronting an entirely different apparatus, an entirely different rationality - both of which require us to produce radically new concepts? (Mbembe, 2016: 32) 
The reason for this is not difficult to ascertain: the globe is still going through the globalization and solidification, even amidst various crisis, of a civilization system that has coloniality as its basis.

Therefore, the continued unfolding of Western modernity is also the reinforcement, through crude and vulgar repetitions as well as more or less creative adjustments, of coloniality. This is reflected in contemporary "development" policies, nation-state building practices, widespread forms of policing, surveillance, and profiling, various forms of extractivism, the increasing concentration of resources in the hands of the few, the rampant expression of hate and social phobias, and liberal initiatives of inclusion, among other forms of social, economic, and political control. (1)

Too many times some academics state that they agree with the principles of a struggle, but not with the practices of those advancing the struggle. They also feel that their job is to comment on the excesses that they observe. And they tend to think that if they are critical of the state or of the established order, that they need to engage in some equal opportunity criticism and target the movements as well-as if the state and the movements were in a horizontal plane. Everything takes place at the level of knowledge and with the liberal values of supposed distance and neutrality. (7)

Addressing colonialism and decolonization as anything more than past episodes or events raises anxieties and fears: anxieties about the legitimacy of the normative citizen-subject and the social, political, and economic order that sustains it, and fears about the very presence and the potential action of those who typically address these topics in this way-that is, the colonized. (8)

Typical responses to raising the question about the meaning and significance of colonization and decolonization are visceral and aim to relativize the value of the questions as well as to undermine the position of the colonized as a questioner. (8)

\section{References}

Appiah.K.A. Is the Post- in Postmodernism the Post- in Postcolonial? Critical Inquiry, 17(2): 336-357

Fanon, F. (2004) The wretched of the earth, Cape Town: Kwela Books. 
Giroux, H. (1992b) Postcolonial ruptures and democratic possibilities: Multiculturalism as antiracist pedagogy, Cultural Critique, 21: 5-39

Grosfoguel. R. (2007) The epistemic decolonial turn, Cultural Studies, 21 (2-3): 211-223.

Mackenzie, C. \& Scully, J.L. (2007) Moral Imagination, Disability and Embodiment Journal of Applied Philosophy, 24(4): 335 - 351.

Maldonado-Torres, N. (2007) On Coloniality of Being, Cultural Studies, 21(2): 240 - 270.

Maldonado-Torres, N., 'Thinking Through the Decolonial Turn: Post-continental Interventions in Theory, Philosophy, and Critique-An Introduction', Transmodernity: Journal of Peripheral Cultural Production of Luso-Hispanic World, 1(2) Fall (2011).

Mamdani, M. (2016) Between the public intellectual and the scholar: decolonization and some post-independence initiatives in African higher education, INTER-ASIA CULTURAL STUDIES, 17 (1): 68-83.

Mbembe, A., 2016, 'Decolonising the university: New directions', Arts \& Humanities in Higher Education 15(1), 29-45

McKaiser, E., 2016, 'Epistemic injustices: The dark side of academic freedom', 2016 DCS Oosthuizen Academic Freedom Memorial Lecture, Rhodes University, Grahamstown, 30 May, viewed 17 June 2016, from http://www.iol.co.za/news/ epistemic-injustices-the-darkside-of-academic-freedom-2029747

McLaren, P. (Ed.) (1995) Postmodernism, postcolonialism and pedagogy, Australia: James Nicholas Publishers

Mignolo, W. D., 'Introduction: Coloniality of Power and De-colonial Thinking', Cultural Studies, 21(2-3) (2007): 159.

Molefe, T.O., 2016, 'Oppression must fall: South Africa's revolution in theory', World Policy Journal 33(1), 30-37.

Wa Thiong'o, N. (1981) Decolonising the mind: The politics of language in African literature. London: James Currey. 
Nuraan Davids

Stellenbosch University

South Africa

nur@sun.ac.za 